\title{
The Relationship Of Sanitation And Refill Water Quality With Stunting Events In The Work Area Of Community Health Centers Titi Papan In Medan Deli District
}

\author{
Sri Bulan Nasution ${ }^{1 *}$, Endang Sofia $\mathrm{S}^{2}$, Adi Rahmat ${ }^{3}$, Murni Sari ${ }^{4}$ \\ 1,2,3 Medical Laboratory Technology, Poltekkes Kemenkes Medan, Medan Indonesia. \\ ${ }^{4}$ North Sumatra Provincial Health Office, Sumatera Utara, Medan, \\ North Sumatra 20155, Indonesia. \\ * Corresponding Author: \\ Email: fauzaabulqoiss@gmail.com
}

\begin{abstract}
.
Poor water quality is associated with various water-related diseases, as well as economic losses due to medical expenses and reduced productive days due to illness. According to him, proper drinking water is not necessarily safe. Sanitation is a public health effort that focuses on monitoring various environmental factors in the provision of clean water, disposal of human waste (latrines), waste management and waste water disposal that affect health status. Stunting is a condition where the child's growth is disturbed so that the child becomes shorter than the normal height of the child's age obtained from height measurements. This study aims to determine the quality of refilled water or drinking water consumed by families from refill drinking water depots or drinking water cooked by stunting families in the working area of Titi Papan Health Center. This type of research is descriptive research, with the research design is cross sectional. The result of this study is that sanitation and drinking water quality are significantly related to the incidence of stunting in the working area of the Titi Papan Public Health Center, Medan Deli District. The most dominant variable related to the incidence of stunting at the Titi Papan Health Center, Medan Deli District, was sanitation with a PR value of 16,212 and $p<0.05$, this means that good sanitation has 16 times the chance of not having stunting compared to poor sanitation.
\end{abstract}

Keywords: Drink water, sanitation, stunting

\section{INTRODUCTION}

Sanitation is a public health effort that focuses on monitoring various environmental factors that affect human health status. Basic sanitation efforts include the provision of clean water, disposal of human waste (latrines), waste management (garbage bins) and waste water disposal. [1] Sanitation is a public health effort that focuses on monitoring various environmental factors that affect human health status. Basic sanitation efforts include the provision of clean water, disposal of human waste (latrines), waste management (garbage bins) and waste water disposal. [2] Stunting is a condition where the child's growth is disturbed so that the child becomes shorter than the normal height of the child for his age which is obtained from the measurement of the child's height for age $(\mathrm{TB} / \mathrm{U})$ where the z-score from the results of the $T B / \mathrm{U}$ measurement is less than -2 SD.[3] Medan Deli District consists of several sub- 
districts, one of which is Titi Papan Village, Medan City which is developing as a service, trade, industrial settlement area and others.

Administratively, Titi Papan Village consists of 18 (eighteen) neighborhoods with an area of 318.9 ha and a population of 23,558 people consisting of 5987 families. From the data of environmental health officers at the Titi Papan Health Center in the village, there are 35 refill water depots spread from 18 neighborhoods.Titi Papan Village needs attention in dealing with stunting cases, so this encourages researchers to conduct research from environmental health aspects about the relationship between hygiene and environmental sanitation with stunting in toddlers in Medan Deli District.The purpose of this study was to determine the sanitation and quality of refill drinking water produced by refill drinking water depots in the working area of Titi Papan Village based on physical, chemical and microbiological variables. [4]

\section{METHODS}

This type of research is an analytical survey with a cross sectional approach. This research was carried out in the working area of the Titi Papan Health Center, Medan Deli District, Sanitation Depot obtained through interviews and direct field observations. The type of data used in this study is primary data obtained from the results of checking the quality of refilled water and the sanitation hygiene of refilled water depots, while secondary data for the community there are stunting sufferers obtained from the local health center for sampling.Drinking water quality parameters, which include physical, chemical, and bacteriological parameters based on Drinking Water Quality Standards in accordance with Minister of Health Regulation No.492/Menkes/Per/IV/2010.Parameters that are directly related to health These parameters are divided into 2 categories:

1. Microbiological Parameters : a. Eschericia coli : 0 quantity per $100 \mathrm{ml}$ sample, b. Total Coliform Bacteria: 0 number per $100 \mathrm{ml}$ sample

2. Inorganic Chemical Parameters : $a$. Arsenic : $0.01 \mathrm{mg} / \mathrm{L}, b$. Fluoride : $1.5 \mathrm{mg} / \mathrm{L}$, c. Cadmium : $0.003 \mathrm{mg} / \mathrm{L}, d$. Nitrite (as NO2-): $3 \mathrm{mg} / \mathrm{L}$, and $e$. Nitrate (as NO3- ): 50 $\mathrm{mg} / \mathrm{L}$

3. Parameters that are not directly related to health : 1. Physical Parameters (a. Smell: no smell, b. Color 15 TCU, c. Turbidity : 5 NTU, d. Taste: no taste) [5]

\section{Univariate Analysis}

Univariate analysis was carried out to see the frequency distribution of the respondent's identity, the independent variable (sanitation and drinking water quality) and the dependent variable (stunting incidence). [6]

\section{Bivariate Analysis}

Data analysis was carried out on two variables that were thought to be related or correlated. The test used in this study is a statistical test using the Pearson Product Moment test. If the calculation results show the value of $r-\operatorname{arithmetic}>r-$ table or $p$ 
value $<$ p value (0.05) then it is said (Ho) is rejected, meaning that both variables have a statistically significant relationship and see OR. [6]

\section{Multivariate Analysis}

Multivariate analysis was used to look at the relationship between the independent variables and the dependent variable together and to find the most dominant variable associated with stunting using multiple logistic regression tests through the following steps. [6]

\section{RESULT AND DISCUSSION}

Characteristics of respondents include; age, gender, marital status, home ownership status and type of drinking water facilities. The results showed that the lowest respondent was 25 years old and the highest was 65 years old with the highest age being 25-34 years, as many as 25 people (71.4\%). Based on gender, there were more men, as many as 18 people $(51.4 \%)$ and the rest were women, as many as 17 people $(48.6 \%)$. Based on marital status, more marital status, as many as 31 people $(88.6 \%)$, the rest of the marital status is divorced, namely 4 people $(11.4 \%)$. Based on the ownership status of the house, most of the people rented, namely 30 people $(85.7 \%)$ the rest owned by themselves, namely 5 people $(14.3 \%)$ and based on the type of drinking water facilities, the majority of refilled water was 22 people $(62.9 \%)$, the rest drilled wells/pumps as many as 9 people (25.7\%) and pipe plumbing, namely 4 people $(11.4 \%)$.

Table 1. Distribution of Respondents Characteristics Based on Identity

\begin{tabular}{clcc}
\hline \multirow{2}{*}{ Number Description } & \multicolumn{2}{c}{ Respondent Identity } \\
\cline { 3 - 4 } & & f & \% \\
\hline 1 & Age & 25 & 71.4 \\
& 25-34 years old & 8 & 22.9 \\
& 35-44 years old & 1 & 2.9 \\
& 45-54 years old & 1 & 2.9 \\
\multirow{2}{*}{2} & 65-74 years old & & \\
& Gender & 18 & 51.4 \\
& Male & 17 & 48.6 \\
3 & Female & & \\
& Status & 31 & 88.6 \\
& Married & 4 & 11.4 \\
4 & Divorced & & 14.3 \\
& Home Ownership Status & 5 & 85.7 \\
& One's own & 30 & 50 \\
5 & Rent & 17 & 62.9 \\
& Type of drinking water & 22 & 11.4 \\
& Refill Water & 4 & 25.7 \\
\hline & Plumbing & 9 & $\mathbf{1 0 0 , 0}$ \\
\hline
\end{tabular}




\section{Relationship between sanitation and stunting}

Based on sanitation, it is known that from 27 respondents who have poor sanitation, there are 20 people (74.1\%) stunting and 7 people (25.9\%) have no stunting. Based on the results of the correlation test, $\mathrm{p}$ value $<0.05$ was obtained, namely $\mathrm{p}=$ 0.032 , this indicates that there is a relationship between sanitation and the incidence of stunting. OR value $=2.893 ; 95 \% \mathrm{CI}=1.393-52.748$, this means that respondents with poor sanitation are estimated to be 3 times more likely to have stunting compared to respondents with good sanitation.

Table 2. Relationship between sanitation and stunting

\begin{tabular}{|c|c|c|c|c|c|c|c|c|c|c|}
\hline \multirow{3}{*}{ Variable } & \multicolumn{4}{|c|}{ Stunting } & \multirow{2}{*}{\multicolumn{2}{|c|}{ Total }} & \multirow{3}{*}{$P$} & \multirow{3}{*}{ OR } & \multicolumn{2}{|c|}{$95 \% \mathrm{CI}$} \\
\hline & \multicolumn{2}{|c|}{$\begin{array}{c}\text { Non- } \\
\text { Stunting }\end{array}$} & \multicolumn{2}{|c|}{ Stunting } & & & & & Lower & Upper \\
\hline & $\mathbf{N}$ & $\%$ & $\mathbf{n}$ & $\%$ & n & $\%$ & & & & \\
\hline Sanitation & & & & & & & & & & \\
\hline Good & 6 & 75,0 & 2 & 25,0 & 8 & 100,0 & 0,032 & 2,893 & 1.393 & 52.748 \\
\hline $\mathrm{Bad}$ & 7 & 25,9 & 20 & 74,1 & 27 & 100,0 & & & & \\
\hline
\end{tabular}

Relationship of Drinking Water Quality with Stunting Incidence

Based on the quality of drinking water, it is known that of the 14 respondents whose water quality examination results were not good, there were 12 people $(85.7 \%)$ stunting and $2(14.3 \%)$ did not. Based on the results of the correlation test, the value of $\mathrm{p}<0.05$ was obtained, namely $\mathrm{p}=0.034$, this indicates that there is a relationship between drinking water quality and the incidence of stunting. OR value $=1,800 ; 95 \%$ $\mathrm{CI}=1.095-2.959$, this means that respondents with poor drinking water quality are estimated to be 1.8 times more likely to have stunting compared to respondents with good sanitation.

Table 3. Relationship of Drinking Water Quality with Stunting Incidence

\begin{tabular}{|c|c|c|c|c|c|c|c|c|c|c|}
\hline \multirow{3}{*}{ Variable } & \multicolumn{4}{|c|}{ Stunting } & & & \multirow{3}{*}{$\boldsymbol{P}$} & \multirow{3}{*}{ OR } & \multicolumn{2}{|c|}{$95 \%$ CI } \\
\hline & \multicolumn{2}{|c|}{$\begin{array}{c}\text { Non- } \\
\text { Stunting } \\
\end{array}$} & \multicolumn{2}{|c|}{ Stunting } & \multicolumn{2}{|c|}{ Total } & & & Lower & Upper \\
\hline & $\mathbf{N}$ & $\%$ & $\mathbf{N}$ & $\%$ & $\mathbf{n}$ & $\%$ & & & & \\
\hline \multicolumn{11}{|c|}{ Water Quality } \\
\hline Good & 11 & 52,4 & 10 & 47,6 & 21 & 100,0 & 0,034 & 1.800 & 1.095 & 2.959 \\
\hline $\mathrm{Bad}$ & 2 & 14,3 & 12 & 85,7 & 14 & 100,0 & & & & \\
\hline
\end{tabular}

Multivariate Analysis

Multivariate analysis was used to look at the relationship between the independent variables and the dependent variable together and to find the most dominant variable associated with stunting using multiple logistic regression tests through the following steps.

1. Conduct bivariate analysis on each variable with the aim of estimating the role of each variable.

2. Selecting potential variables to be included in multivariate analysis, namely variables with $p$ value $<0.25$ 
3. After identifying the significant variables, further testing is carried out together to identify the most dominant factor influencing the incidence of stunting

4. Based on the correlation test, it is known that from the 2 (two) independent variables tested, 2 (two) variables have a $\mathrm{p}$ value $<0.25$, so that all independent variables are included or become candidates in multivariate analysis.

The results of the logistic regression test using the enter method showed that sanitation and drinking water quality were associated with stunting. The test results can be explained as follows:

a. Sanitation has an OR value of 16,212 and $p<0.05$, namely $p=0.024$, this means that good sanitation has 16 times the chance of not having stunting compared to poor sanitation.

b. Drinking water quality has an OR value of 1.083 and $p<0.05$, which is 0.033 , this means that drinking water quality is not good, the chance of stunting is 1 time compared to good drinking water quality.

c. The sanitation variable is the dominant variable related to the incidence of stunting with the largest OR value, which is 16.212 .

The results of the multiple logistic regression test can be seen in Table 4.4

Tabel 4.4. Relationship between Sanitation and Drinking Water Quality with Stunting Incidence

\begin{tabular}{llcccr}
\hline \multirow{2}{*}{ Nu. } & Variable & \multirow{2}{*}{ Sig. } & \multicolumn{2}{c}{ Exp.B(O } & \multicolumn{2}{c}{$\mathbf{9 5 \%}$ CI For Exp.B } \\
& $\mathbf{R})$ & Lower & Upper \\
\hline 1 & Sanitation & 0,024 & 16.212 & 1.471 & 178.695 \\
2 & Drink Water Quality & 0,033 & 1.083 & 1.008 & 1.816 \\
Constant & .930 & .827 & & \\
\hline
\end{tabular}

\section{CONCLUSION}

Based on the results of research and discussion on the relationship between sanitation and refill water quality with stunting events in the Titi Papan Public Health Center, Medan Deli District in 2021, the conclusions and research suggestions are as follows: Sanitation and drinking water quality are significantly related to the incidence of stunting in the working area of the Titi Papan Public Health Center, Medan Deli District. The most dominant variable related to the incidence of stunting at the Titi Papan Health Center, Medan Deli District, was sanitation with a PR value of 16,212 and $\mathrm{p}<0.05$, this means that good sanitation has 16 times the chance of not having stunting compared to poor sanitation.

\section{ACKNOWLEDGMENTS}

The author is grateful to the Operational Assistance of State Universities for supporting this research activity. We also thank the ranks of Poltekkes Kemenkes Medan in the field of research centers and community service who have participated in 
helping the process of distributing this research report so that it is created properly and correctly. And I thank the Head of the Titi Papan Medan Health Center, Mr. Mohd Mukhlis, M.Kes and Mrs. Hariyani, the staff of Nutrition-knowledge who have helped me and the team in the process of collecting stunting data at the research location.

\section{REFERENCES}

[1] Owino, V., Ahmed, T., Freemark, M., \& Kelly, P. (2016). Environmental Enteric Dysfunction and Growth Failure / Stunting in Global Child Health. Pediatrics 138(6):e2016064. https://doi.org/10.1542/peds.2016-0641

[2] Soemirat. S, Environtmal Health, UGM, Yogyakarta, 2004, h. 10. WHO. 2013. Health Through Safe Drinking Water and Basic Sanitation. http://www.who.int/water_sanitation_health/mdg1/en/ accessed tgl 2 April 2014.

[3] World Health Organization (2014). Global nutrition targets 2025 stunting policy brief. Geneva, Switzerland: World Health

[4] Indonesian Ministry of Health. 2010. Guidelines for the Implementation of Sanitation Hygiene for Drinking Water Depots. Directorate of Environmental Health, Director General of PPPL: Jakarta.

[5] Ministry of Health of the Republic of Indonesia, Regulation of the Minister of Health of the Republic of Indonesia No. 492/MENKES/PER/IV/2010. Regarding Drinking Water Quality Requirements. Jakarta: MOH; 2010

[6] Notoatmodjo, Soekidjo. 2010. Health Research Methodology. Jakarta: Rineka Cipta 